\title{
Slow Fashion: Ethics and Sustainability in the Fashion Batik Industry
}

\author{
Eristia Lidia Paramita ${ }^{1}$ \\ eristia.paramita@uksw.edu \\ Faculty of Economics and Business, Universitas Kristen Satya Wacana \\ J1. Diponegoro No. 52-60, Salatiga 50711, Central Java, Indonesia
}

\begin{abstract}
Small Medium Enterprises (SMEs) need to adapt themselves on the dynamic environment. They are concerned on the environmental and sustainability issues thus produce slow fashion. There are only limited numbers of SMEs who practice in ecofriendly products. Therefore this paper aims to describe the SMEs' practices on slow fashion, explain the capabilities needed to be success in the dynamic green environment and suggest the marketing strategies to compete in the sustainable green market of slow fashion product.
\end{abstract}

Keywords: slow fashion, ethics, sustainability, batik, small medium enterprises

\section{Introduction}

Being green is known as an important part for human and business environment. The movement to the green environment has turned into market demands [16]. As part to the business matter, firms are concerned on the environmental and sustainability issues [2]. Consumers' attitude is changing towards sustainability, especially on consuming green product. Further, perceived quality, price, packaging, and functional value are used as a factor influencing consumers purchasing decisions [15]. This also influence the human needs on using the environmentally goods.

People are aware to the environmental issues. Fashion is the second largest industrial polluter, second only to oil. It supported by the facts that textile waste has increased by massive $811 \%$ from 1960 to 2015 . Moreover, clothing production has more than doubled from 2000 and yet people do not use $40 \%$ of the clothes they buy. There are lots of campaigns to change people's mind on respecting the nature through green movements. The actions lead the idea to change from the fast fashion (mass production and low price - economics of scale) to 
slow fashion movements. The slow fashion consumers have the willingness to pay a higher price range for clothing [12]. They purchase on ethical and organics alternatives products.

United Nation has set the Sustainable Development Goals (SDG), consisting of 17 goals as a world development agenda for human welfare. These goals can be universally applied and measured in three dimensions, namely environment, social and economy. Moreover, ASEAN Economic Community (AEC) developed several objectives to foster a culture of fair competition. To lay on this, The ASEAN Policy Blueprint for Small Medium Enterprises (SMEs) Development (APBSD) 2004-2014 outlines the framework for its development in the ASEAN region. The objectives are to enhance the competitiveness and dynamism of ASEAN SMEs by facilitating their access to information, market, human resource development, and skills, finance as well as technology and more liberalized on the trading environment.

SMEs play a key role in the economic growth in most countries in the Asia-Pacific region [10] including Indonesia. As part of the economy, SMEs contribute to the economy significantly and also the environmental problems due to the increase of small business activities nowadays [18]. SMEs need to adapt themselves to the market developments (new business model) as it is needed to build on the strengths of their resource bases and activity systems [4]. Further, SMEs should be addressed environmentally responsible in their activities.

In order to be responsible to the environment, SMEs produce slow fashion product, as the opposite to fast fashion. Slow fashion combines ecology, ethnic and green movements due to human health-friendly, fair environmental, economic and social system development [1]. Amongst various industries, Batik is one of the industries that practice these actions. Within the industry, Batik is responsible for water pollution since it utilized a lot of chemicals. The waste contains wax, heavy metal suspended solids and dyes in painting and coloring processes [18].

There is a paradox in batik production. The original batik, actually, is processed naturally (handwriting batik, stamp batik and combination of handwriting batik and stamp batik). It uses natural dyes eco-friendly [7], thus the production uses natural-colored batik [6] are categorized as slow production. Otherwise, since the batik production process applies the principle of industrialization that pursues speed, a scale of production, efficiency, and optimization of production, batik production has actually applied the principle of fast 
production. This can be seen in the production of printed batik that use coloring machine materials. It also occurs in original batik productions are colored with non-ecological paint [1].

The transformation practice of slow production is also seen in the motion of batik production used by the batik industry, namely from the factory production mode to the "putting-out" system (POS) mode. In this process, the transfer happens to the production chain; from the factory to the home-workers [9]. So, the unity of batik production from material production to fashion products is relatively long. There are many actors in it that are physically relatively far apart. Technically there are problems in the distribution of knowledge, skills, and time in production. This technically consumes a long time. Consequently, current fashion system has been questioned, whether this process is included in the principle of slow fashion? [8].

Slow fashion is the opposite of fast fashion [11]. Slow fashion is firstly introduced by [5]. It is an alternative to socially and environmentally unsustainable practices resulting from the fast fashion system. It also appears by slowing down the production cycle of clothing that help the environment and people live in a healthier way and regenerate of the environment [3]. Slow fashion combines ecology, ethnic and green movements that can be interpreted as sustainable fashion. Due to the human heath friendly, fair environmental, economic and social system development [1]. Slow fashion is also based on sustainability within the fashion industry and design that combines high quality, small lines, regional productions and fair labor conditions [13].

There are only limited SMEs that concern on environmental issues. To become a sustainable business; SMEs need to constantly adapt to changing market and dynamics environments [14], [8]. In Indonesia, there are only limited numbers of SMEs who practice eco-friendly actions. Therefore, the impetus is more for SMEs from small domestic markets adapt themselves to the dynamic green environment. Further, it informs some issues to the research questions that this paper aims to address. First, how do SMEs produce Batik (in production)? Second, how do SMEs evaluate themselves that conduct slow fashion? Third, what are the capabilities of competing in eco-friendly products? Four, how the entrepreneurs able them competing in global change thus in the same time the SMEs compete inside sustain global market (slow fashion industry)? 


\section{Methodology}

The case study methodology is going to be used to obtain a clearer picture of SMEs [17] and an empirical investigation of the Indonesia slow fashion SMEs phenomenon will be discussed [19] and a mini-theory developed [11]. The target population for this study is SMEs (in Central Java Province) in slow fashion industries. The level of analysis in this study is the integrated actors of slow fashion's production and consumption channels of product (i.e the SMEs who produce slow fashion product). Whereas the unit of data collection is going to be the individual owner/founder of the slow fashion SMEs, which have the differences on position and role, knowledge and practical ways thus contributes as integrated slow fashion perspectives. Observation, in-depth interview and Focus Group Discussion are going to be used to obtain the data.

\section{References}

[1] Antanaviciute, A., \& Dobilaite, V. (2015). Principles of Slow Fashion Application in Clothing Collection Creation. Environmental Research, Engineering and Management, 54-59.

[2] Boztepe, A. (2012). Green Marketing and Its Impact on Consumer Buying Behavior. European Journal of Economic and Political Studies, 5-21.

[3] Cataldi, C., Dickson, M., \& Grover, C. (2010). Slow Fashion: Tailoring a Strategic Approach Towards Sustainability. Sweden: Institute of Technology Sweden.

[4] De Wit, B., \& Meyer, R. (2005). Strategy Synthesis: Resolving Strategy Paradoxes to Create Competitive Advantage. Italy: Thomson.

[5] Fletcher, K. (2010). Slow Fashion: An Invitation for System Change. Fashion Practice, 259-265.

[6] Handayani, W., Kristijanto, A. I., \& Hunga, A. I. (2018). A Water Footprint Case Study in Jarum Village, Klaten, Indonesia: The Production of Natural-Colored Batik. Environ Dev Sustain, 1-14.

[7] Handayani, W., Kristijanto, A. I., \& Hunga, A. I. (2018). Are Natural Dyes Eco-Friendly? A Case Study on Water Usage and Wastewater Characteristics of Batik Production by Natural Dyes Application. Sustainable Water Resources Management, 1-11.

[8] Hooley, G., Piercy, N., \& Nicoulaud, B. (2012). Marketing Strategy and Competitive Positioning Fifth Edition. United Kingdom: Prentice Hall.

[9] Hunga, A. I. (2011). Uncover the Invisible: Home-workers in Micro-Small-Medium Industries Based on "Putting-out" System (The CSe Study of The Batik and Batik Convection Industry in a Sragen-Surakarta-Sukoharjo Cluster of Indonesia). The International Journal of Interdiscplinary Social Sciences, 311-322.

[10] Jin, H., \& Hurd, F. (2018). Exploring the Impact of Digital Platforms on SME Internationalization: New Zeland SEMs Use of the Alibaba Platform for Chinese Market Entry. Journal of Asia-Pasific Business, 72-95. 
[11] Jonker, J., \& Pennink, B. (2010). The Essence of Research Methodology: A Concise Guide for Master and PhD Students in Management Science. Heidelberg, Germany: Springer.

[12] Jung, S., \& Jin, B. (2016). From Quantity to Quality: Understanding SLow Fashion Consumers for Sustainability and Consumer Education. International Journal of Consumer Studies, 410-421.

[13] Liu, C., Pookulangara, S., \& Shephard, A. (2017). Who Buys Slow Fashion: A Study of Lifestyle Characterisctics and Motivationg Factors among Young Consumers. International Textile and Apparel Association (s. 1-2). ST. Petersburg, Florida: Iowa State University.

[14] Mazzarol, T. (2004). Strategic Management of Small Firms: A Proposed Framework for Entrepreneurial Ventures. 17th Annual SEAANZ COnference, (s. 1-23). Brisbane, Queensland.

[15] Paramita, E. L., \& Wibisono, B. (2015). Consumer's Perception Toward Indomaret Private Label Brand in Salatiga. Jurnal Ekonomi dan Bisnis, 175-188.

[16] Sanidewi, H., \& Paramita, E. L. (2018). The ROle of Perceived Green Marketing and Brand Equity on Green Purchasing Decision. Diponegoro International Journal of Business, 14-25.

[17] Sekaran, U., \& Bougie, R. (2016). Research Methods for Business A Skill-Building Approach Seventh Edition. Italy: Wiley.

[18] Yaacob, M., \& Zain, N. M. (2016). State and Security Crises in Nigeria's fourth Republic (1999-2015): A Paradox of Democracy. International Journal of Development and Sustainability, 87-97.

[19] Yin, R. K. (2009). Case Study Research: Design and Methods; 4th ed. Thousand Oaks: Sage Publications. 